\title{
Antihypertensive activity of ethanol extract combination of Anredera cordifolia (Ten.) v. Steenis and Sonchus arvensis L. leaves on angiotensin II- induced male wistar rat
}

\author{
Elin Yulinah SUKANDAR ${ }^{1 *}$ (D), Afrillia Nuryanti GARMANA ${ }^{1}$ (D), Anggi Utri AIDASARI ${ }^{1}$ (D), \\ Audrey Amira CRYSTALIA $1 * *$ (D)
}

1 Research Department of Pharmacology, School of Pharmacy, Bandung Institute of Technology, Bandung, Indonesia.

* Corresponding Author. E-mail: elin@fa.itb.ac.id (E.Y.S.); Tel. +62-22-912 96240.

** Corresponding Author. E-mail amiracrystalia@gmail.com (A.A.C); Tel. +62-81-616 71950.

Received: 08 March 2019 / Revised: 28 July 2019 / Accepted: 02 August 2019

\begin{abstract}
Hypertension is an important risk factor of cardiovascular disease which is the leading cause of death. Traditionally, many plants are used to lower blood pressure including Anredera cordifolia (Ten.) v. Steenis and Sonchus arvensis L.. Previous studies found that both plants showed antihypertensive activity through inhibiting angiotensin converting enzyme and inducing diuresis. The aim of this study is to evaluate the antihypertensive effect of Anredera cordifolia (Ten.) v. Steenis leaves extract (ACLE) and Sonchus arvensis L. leaves extract (SALE) combination on hypertensive animal induced with angiotensin II. In this study, blood pressure measurement was done using CODA ${ }^{\circledR}$ tail-cuff blood pressure system plethysmograph. After initial measurement of blood pressure, extracts were administered orally according to the respective groups as follow: ACLE 50, ACLE 100, SALE 50, SALE 100, ACLE-SALE 25-25, and ACLE-SALE 50-50 mg/ kg bw. After 1 hour, angiotensin II $100 \mu \mathrm{g} / \mathrm{kg}$ bw was administered then the blood pressure was re-measured. ACLE 50 and ACLE-SALE $25-25 \mathrm{mg} / \mathrm{kg}$ bw were able to significantly lower blood pressure compared to positive control group $(\mathrm{p}<0.05)$, while SALE $50 \mathrm{mg} / \mathrm{kg}$ bw was not. Significant prevention of blood pressure elevation was seen in ACLE-SALE $25-25 \mathrm{mg} / \mathrm{kg}$ bw group with percent inhibition of $54.77 \%$ for systole and $67.6 \%$ diastole. ACLE 50 and ACLE-SALE $25-25 \mathrm{mg} / \mathrm{kg}$ bw were able to reduce the effect of angiotensin II and possibly act as angiotensin receptor antagonist. Furthermore, in extract combination, SALE of $25 \mathrm{mg} / \mathrm{kg}$ bw could reduce the dose of single ACLE as antihypertension by half the individual dose.
\end{abstract}

KEYWORDS: Antihypertension; angiotensin II receptors blocker; Anredera cordifolia; Sonchus arvensis.

\section{INTRODUCTION}

Cardiovascular diseases is the leading cause of death in the world and also in Indonesia $[1,2]$. Hypertension is one of the most important risk factor of cardiovascular diseases. In Indonesia, the prevalence of hypertension was $25.8 \%$ in 2013 [3]. Untreated hypertension can cause major complication such as stroke, coronary heart disease, diabetes, kidney failure, and blindness [4]. Long term use of antihypertensive drugs can cause harmful side effects. In order to find alternative drug for treating hypertension with better safety profile, researches have been focusing on anti-hypertension originated from natural resources or herbal medicines.

In Indonesia, a lot of plants have been used traditionally by people to help lower blood pressure. Examples of it are Anredera cordifolia (Ten.) v. Steenis and Sonchus arvensis L.. Anredera cordifolia (Ten.) v. Steenis is known as madeira vine in English and binahong in Indonesia while Sonchus arvensis L. as perennial sowthistle in English and tempuyung in Indonesia. Anredera cordifolia (Ten.) v. Steenis contains alkaloid, flavonoid, phenol, tannin, steroid/triterpenoid, saponin, and glycosides [5]. Saponin content in Anredera cordifolia (Ten.) v. Steenis leaves was found to amount $28.14 \pm 0.22 \mathrm{mg} / \mathrm{g}$ of dry weight material [6]. It was also reported that apigenin and apigetrin are two of the main secondary metabolites in Anredera cordifolia (Ten.) v. Steenis [7]. Previous study by Wahjuni found that Anredera cordifolia (Ten.) v. Steenis leaf extract contains phytol and n-hexadecanoic acid [8]. Anredera cordifolia (Ten.) v. Steenis leaf has been found to have antihypertensive effect with vasodilatory effect through NO pathway and adrenergic receptor antagonist as

How to cite this article: Sukandar EY, Garmana AN, Aidasari AU, Crystalia AA. Antihypertensive activity of ethanol extract combination of Anredera cordifolia (Ten.) v. Steenis and Sonchus arvensis L. leaves on angiotensin II- induced male wistar rat. J Res Pharm. 2019; 23(6): 10901097. 
its dominant mechanism of action. Anredera cordifolia (Ten.) v. Steenis also moderately inhibits angiotensin converting enzyme (ACE), acts as weak diuretic, and inhibits calcium channel albeit weakly [9].

Sonchus arvensis L. leaf contains flavonoids in the form of kaempferol, luteolin-7-O-glucoside, apigenin7-O-glucoside [10]; coumarin (scopoletin); taraxaterol; inositol; phenolic acid (cinnamic, coumaric, and vanilic) [11]; triterpenenoid; inositol; and mannitol [12]. Khan found that flavonoid contetnt in Sonchus arvensis L. leaf could reach a maximum of $23.40 \mathrm{mg} / \mathrm{g}$ dry weight [13]. In addition, Khan also found that Sonchus arvensis L. leaf contains $0.871 \pm 0.05 \mu \mathrm{g} / \mathrm{mg}$ dry weight of orientin, $0.455 \pm 0.03 \mu \mathrm{g} / \mathrm{mg}$ dry weight of hyperuside, $0.780 \pm 0.03$ $\mu \mathrm{g} / \mathrm{mg}$ dry weight of quercetin, $0.656 \pm 0.07 \mu \mathrm{g} / \mathrm{mg}$ dry weight of catechin, $0.457 \pm 0.02 \mu \mathrm{g} / \mathrm{mg}$ dry weight of rutin, $0.647 \pm 0.07 \mu \mathrm{g} / \mathrm{mg}$ dry weight of myricetin, and $0.947 \pm 0.1 \mu \mathrm{g} / \mathrm{mg}$ dry weight of kaempferol [13]. Sonchus arvensis L. leaf was found to inhibit ACE [14] and act as diuretic [15]. This research focused on studying the antihypertensive mechanism of both Anredera cordifolia (Ten.) v. Steenis and Sonchus arvensis L. leaves ethanol extract as well as observing the antihypertensive effect of Anredera cordifolia (Ten.) v. Steenis and Sonchus arvensis L. leaves ethanol extract combination on systolic and diastolic blood pressure of angiotensin IIinduced Wistar rats.

\section{RESULTS AND DISCUSSION}

Hypertension is a condition where elevated blood pressure occurs and is closely related to other cardiovascular diseases. According to Joint National Committee (JNC) 8 , a patient with $<60$ years of age is considered to have hypertension if his systolic blood pressure (SBP) is $\geq 140 \mathrm{mmHg}$ and/or diastolic blood pressure (DBP) is $\geq 90 \mathrm{mmHg}$. For a patient with $\geq 60$ years of age, JNC 8 recommends pharmacological treatment to start at SBP $\geq 150 \mathrm{mmHg}$ and/or DBP $\geq 90 \mathrm{mmHg}$. Therefore, the target of blood pressure is $<140 / 90 \mathrm{mmHg}$ for the general population aged $<60$ years and $<150 / 90 \mathrm{mmHg}$ for the general population aged $\geq 60$ years [16]. There are several groups of antihypertensive drugs, one of it is Angiotensin Receptor Blocker (ARB). ARB interferes with the binding of angiotensin II to AT1 receptor through competitively binding with AT1 receptor, which results in the inhibition of angiotensin II effects. Examples of ARB are losartan, valsartan, olmesartan, and candesartan [4]. Valsartan is an example of ARB drug that is highly selective for AT1 receptor. ARB group of drugs is the drug of choice other than ACE inhibitor for a condition where hypertension is accompanied by kidney failure.

Antihypertensive activity assay was done using angiotensin II-induced rats. Angiotensin II is a hormone that is working as a potent but labile vasoconstrictor. Intravenously administered angiotensin II has a half-life of less than 1 minute [17]. Hence, its administration route for the experiment was intraperitoneal due to the very short half-life. Angiotensin II is responsible for elevation of blood pressure when it is bound to AT1 receptor. The binding of angiotensin II on AT1 receptor interacts with Gq causing the activation of phospholipase C (PLC) which then mediated phosphatidylinositol 4,5-biphosphate (PIP2) phosphorylation into inositol triphosphate (IP3) and diacylglycerol (DAG). Subsequently, PKC will be activated then $\mathrm{Ca}^{2+}$ channel will be phosphorylated causing massive influx of $\mathrm{Ca}^{2+}$ in the cytoplasm which in turn resulting in vasoconstriction via activation of myosin light chain kinase (MLCK) $[18,19]$. In neuroendocrine system, activation of AT1 receptor stimulates secretion of aldosterone from adrenal cortex which cause water and sodium retention and also potassium secretion in the kidney. In the central nervous system, angiotensin II elevated thirst therefore induce secretion of antidiuretic hormone (ADH) [4]. Administration of extracts was hoped to be able to inhibit the elevation of blood pressure caused by angiotensin II.

Before conducting the experiment, angiotensin II was tested for its duration of action when administered intraperitoneally. The results showed that in under one minute, angiotensin II was able to increase systolic and diastolic blood pressure. The blood pressure started to decrease at 20 minutes after angiotensin II administration. Figure 1 and 2 below shows the systolic and diastolic blood pressure profile in normal and angiotensin II-induced rats.

In this study, male Wistar rats were used to reduce the effect of endogenously occurring hormones, such as the oestrus cycle in female rats that affect the blood pressure. An hour prior to administration of intraperitoneal angiotensin, all treatment groups received oral administration of treatments (Valsartan as the comparator, AC leaves extract (ACLE) dose $100 \mathrm{mg} / \mathrm{kg}$ bw, ACLE dose $50 \mathrm{mg} / \mathrm{kg}$ bw, SA leaves extract (SALE) dose $100 \mathrm{mg} / \mathrm{kg} \mathrm{bw}$, SALE dose $50 \mathrm{mg} / \mathrm{kg} \mathrm{bw}$, and combination of ACLE and SALE with 50-50 and $25-25 \mathrm{mg} / \mathrm{kg}$ bw respectively). Negative and positive control groups were untreated. The dose of valsartan was determined using the daily dose for adult human which is $80 \mathrm{mg} /$ day. The human dose was converted into rat dose to obtain $7.2 \mathrm{mg} / \mathrm{kg} \mathrm{bw}$. ACLE doses were of 50 and $100 \mathrm{mg} / \mathrm{kg}$ bw were obtained from previous study about mechanism of action of AC leaf as antihypertension [9]. The doses of SALE used for individual 
administration and in its combination with ACLE were determined based on the doses of ACLE to enable direct comparison using the same dose. Extracts and the comparator were suspended in $0.5 \% \mathrm{Na}-\mathrm{CMC}$ to make certain of its homogenous distribution due to the low solubility of SA extracts in distilled water. While the 1 hour gap in administrating the extracts and angiotensin II was done in purpose to allow the absorption of extracts into the bloodstream. All groups except the negative control group received intraperitoneal administration of angiotensin and therefore became hypertensive after administration. Due to not receiving angiotensin administration and was untreated, negative control group was normal rats and used to identify normal blood pressure of rats.

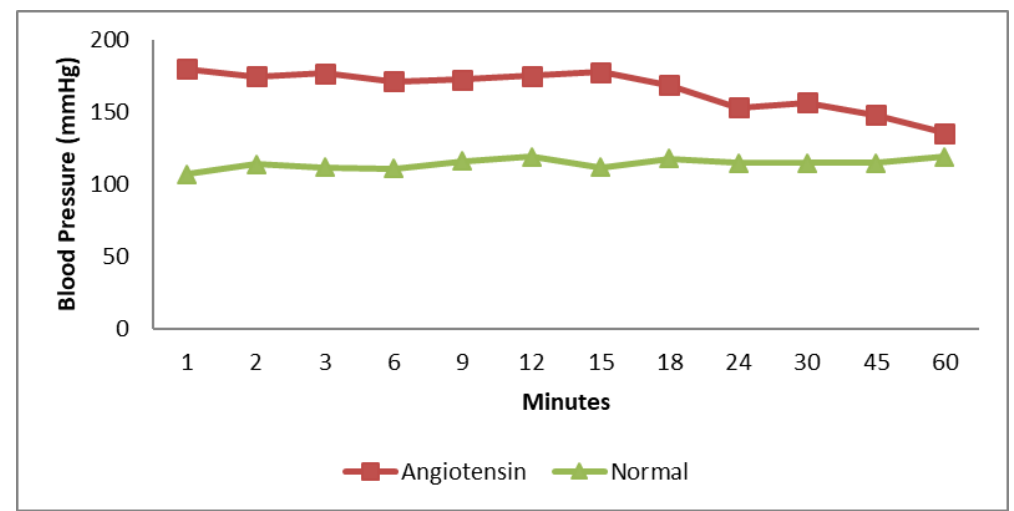

Figure 1. Systolic blood pressure of normal and angiotensin II-induced rats over a period of 60 minutes after angiotensin II administration.

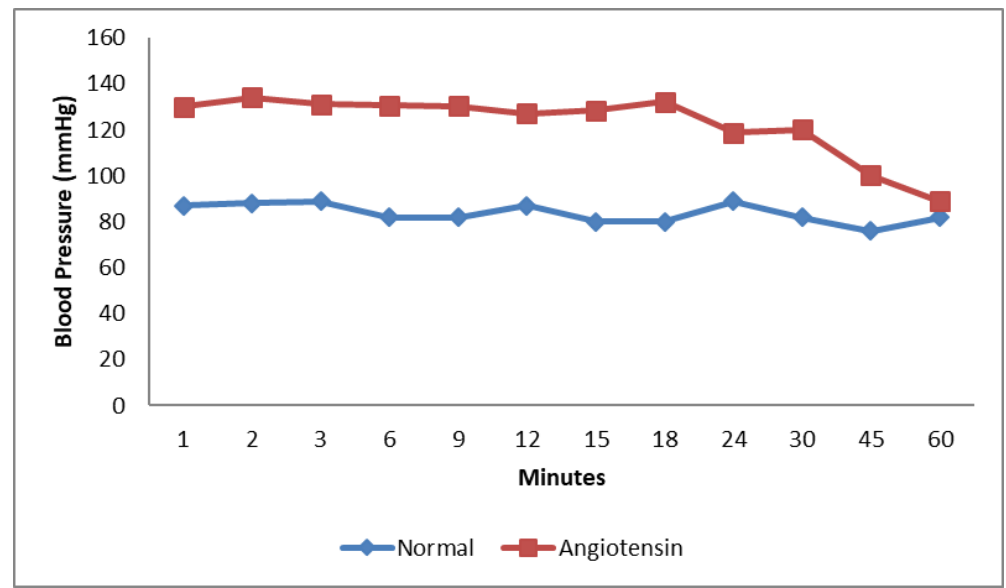

Figure 2. Diastolic blood pressure of normal and angiotensin II-induced rats over a period of 60 minutes after angiotensin II administration.

The measurement results of $\mathrm{T} 0$ showed that the systolic and diastolic blood pressure are across the population are normally distributed. The average of SBP at T0 was $116.86 \mathrm{mmHg}$ while the DBP was 79.66 $\mathrm{mmHg}$. Hence, the statistical analysis was done using one-way ANOVA with LSD post-hoc test. From table 1 , it can be seen that after $100 \mu \mathrm{g} / \mathrm{kg}$ bw of angiotensin II administration the SBP and DBP in positive control group was significantly different $(\mathrm{p}<0.05)$ with negative control group. This showed that the angiotensin II had successfully induced hypertension both systolic and diastolic.

The blood pressure of the experimental groups were compared with angiotensin induced and untreated group (positive control) to determine the ability of extracts in inhibiting the elevation of blood pressure. Table 1 shows that all experimental groups' blood pressure were not significantly elevated except groups administered with SALE $50 \mathrm{mg} / \mathrm{kg}$ bw and ACLE-SALE combination $50-50 \mathrm{mg} / \mathrm{kg}$ bw. SALE administration at dose $50 \mathrm{mg} / \mathrm{kg}$ bw was not adequate to show effect significantly inhibit the blood pressure elevation. The combination of ACLE and SALE at dose of $50 \mathrm{mg} / \mathrm{kg}$ bw each was not showing the statistically significant difference against positive control group albeit the results of ACLE-SALE combination at $25 \mathrm{mg} / \mathrm{kg}$ bw each. Statistically, SBP of ACLE $50 \mathrm{mg} / \mathrm{kg}$ bw (p=0.05), ACLE $100 \mathrm{mg} / \mathrm{kg}$ bw (p=0.002), SALE $100 \mathrm{mg} / \mathrm{kg} \mathrm{bw}$ $(\mathrm{p}=0.015)$, and ACLE-SALE $25-25 \mathrm{mg} / \mathrm{kg}$ bw combination $(\mathrm{p}=0.013)$ significantly differs from positive control 
group. In addition, DBP of ACLE $50 \mathrm{mg} / \mathrm{kg}$ bw (p=0.022), ACLE $100 \mathrm{mg} / \mathrm{kg}$ bw (p=0.018), SALE $100 \mathrm{mg} / \mathrm{kg}$ bw $(p=0.033)$, and ACLE-SALE $25-25 \mathrm{mg} / \mathrm{kg}$ bw combination $(\mathrm{p}=0.027)$ also significantly differs from positive control group. The results showed that the extracts administered which had statistically significant difference with positive control group have activity on AT1 receptor as antagonists of angiotensin II.

Table 1. Systolic and diastolic pressure before and after administration of angiotensin II.

\begin{tabular}{|c|c|c|c|c|}
\hline \multirow{2}{*}{$\begin{array}{l}\text { Groups } \\
(n=3)\end{array}$} & \multicolumn{2}{|c|}{ Before } & \multicolumn{2}{|c|}{ After } \\
\hline & Systole (mmHg) & Diastole (mmHg) & Systole (mmHg) & Diastole (mmHg) \\
\hline Negative Control & $114.27 \pm 3.14$ & $78.95 \pm 4.04$ & $121.69 \pm 7.52$ & $88.48 \pm 4.05$ \\
\hline Positive Control & $116.50 \pm 5.80$ & $77.61 \pm 9.43$ & $167.53 \pm 7.80^{b}$ & $127.89 \pm 21.76^{b}$ \\
\hline $\begin{array}{l}\text { Valsartan } 7.2 \mathrm{mg} / \mathrm{kg} \\
\text { bw }\end{array}$ & $119.81 \pm 13.04$ & $85.58 \pm 13.37$ & $115.66 \pm 3.22$ & $82.11 \pm 8.13$ \\
\hline ACLE $50 \mathrm{mg} / \mathrm{kg}$ bw & $109.25 \pm 7.69$ & $72.75 \pm 7.09$ & $142.41 \pm 5.35^{\mathrm{a}}$ & $101.52 \pm 5.53 \mathrm{a}$ \\
\hline ACLE $100 \mathrm{mg} / \mathrm{kg}$ bw & $114.07 \pm 12.47$ & $74.47 \pm 14.92$ & $138.30 \pm 2.21^{\mathrm{a}}$ & $100.64 \pm 1.42$ a \\
\hline SALE $50 \mathrm{mg} / \mathrm{kg}$ bw & $108.52 \pm 13.13$ & $71.31 \pm 8.87$ & $166.17 \pm 9.56$ & $129.05 \pm 9.99$ \\
\hline SALE $100 \mathrm{mg} / \mathrm{kg}$ bw & $119.91 \pm 7.59$ & $83.80 \pm 6.09$ & $146.34 \pm 14.68^{a}$ & $103.57 \pm 17.27$ a \\
\hline $\begin{array}{l}\text { ACLE-SALE } \\
\text { combination } \\
\mathrm{mg} / \mathrm{kg} \mathrm{bw})\end{array}$ & $122.74 \pm 7.62$ & $86.25 \pm 9.87$ & $145.82 \pm 8.91^{\mathrm{a}}$ & $102.64 \pm 1.08 \mathrm{a}$ \\
\hline $\begin{array}{l}\text { ACLE-SALE } \\
\text { combination } \\
\mathrm{mg} / \mathrm{kg} \mathrm{bw})\end{array}$ & $115.56 \pm 9.68$ & $78.24 \pm 10.66$ & $153.60 \pm 2.94$ & $111.12 \pm 3.46$ \\
\hline
\end{tabular}

a significant difference against positive control $(\mathrm{p}<0.05)$

$\mathrm{b}$ significant difference against negative control $(\mathrm{p}<0.05)$

Table 1 also shown that both SBP and DBP after angiotensin II administration in ACLE-SALE 25-25 $\mathrm{mg} / \mathrm{kg}$ bw group is comparable to that of ACLE $50 \mathrm{mg} / \mathrm{kg}$ bw and SALE $100 \mathrm{mg} / \mathrm{kg}$ bw. The administration of $25 \mathrm{mg} / \mathrm{kg}$ bw of SALE in combination with ACLE $25 \mathrm{mg} / \mathrm{kg}$ bw not only managed to had antihypertensive effect while SALE $50 \mathrm{mg} / \mathrm{kg}$ bw administration did not significantly lower the blood pressure, but also lower the dose of ACLE by $25 \mathrm{mg} / \mathrm{kg}$ bw to produced comparable effect. This indicates that ACLE and SALE showed better antihypertensive effect in combination at lower dose.

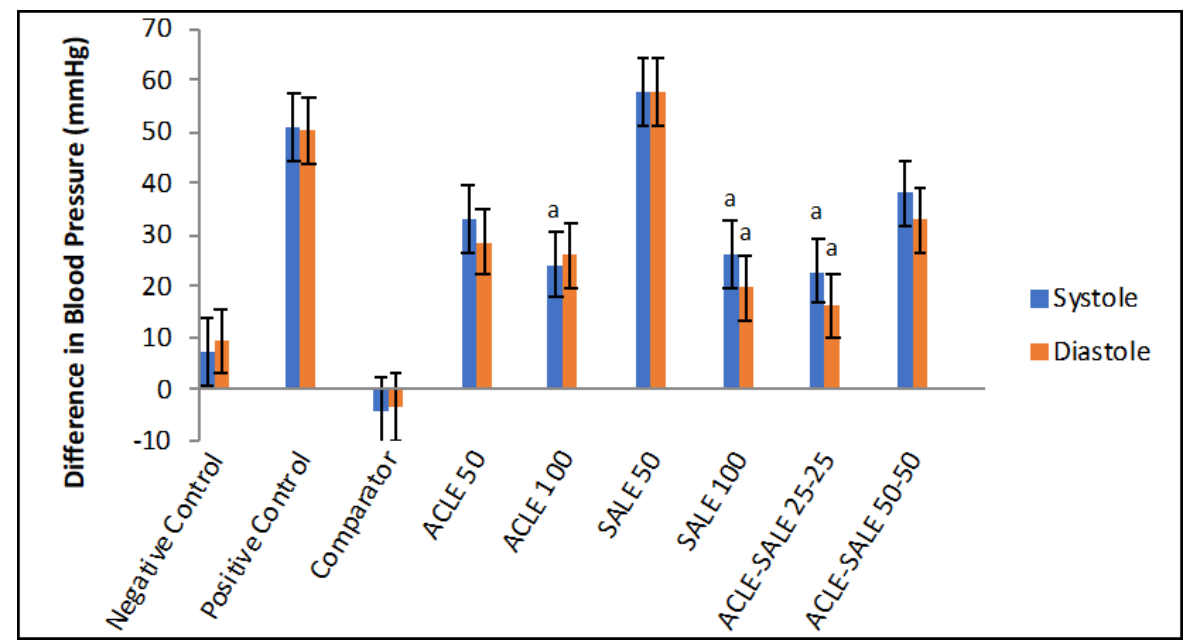

Figure 3. Difference in blood pressure before and after angiotensin II administration; a shows significant difference against positive control group $(\mathrm{p}<0.05)$ statistically analysed using one-way ANOVA. 
The difference in blood pressure was measured by subtracting the before with the after angiotensin II administration shown in table 1 . The difference for each groups were displayed in figure 3 . Figure 3 shows that all groups except comparator group had an increase in the SDP and DBP. The elevation of SBP of ACLE $100 \mathrm{mg} / \mathrm{kg}$ bw and both SBP and DBP of SALE $100 \mathrm{mg} / \mathrm{kg}$ bw and ACLE-SALE (25-25 mg/kg bw) groups were significantly lower than positive control group.

Previous study by Sukandar et al.[7] about the vasodilatory effect of ACLE and SALE on isolated rabbit's aorta and frog's heart showed that ACLE induced vasodilation while SALE induced vasoconstriction. It could be that SALE contains certain compound that is able to cause vasoconstriction and increase the blood pressure. In SALE $50 \mathrm{mg} / \mathrm{kg}$ bw group, the compound responsible for its antihypertensive effect had not achieve its therapeutic concentration in the bloodstream with $50 \mathrm{mg} / \mathrm{kg}$ bw dose while the compound responsible for its vasoconstricting effect was able to affect the blood pressure at the given dose. Hence, the blood pressure was elevated more than the elevation in the blood pressure of positive control group. In contrast, in SALE $100 \mathrm{mg} / \mathrm{kg}$ bw group, the compound responsible for its antihypertensive effect had achieved the therapeutic concentration in the bloodstream with the given dose resulting in the decrease of blood pressure.

Table 2. Percent inhibition of blood pressure elevation.

\begin{tabular}{lcc}
\hline Groups & Systole (\%) & Diastole (\%) \\
\hline ACLE $50 \mathrm{mg} / \mathrm{kg} \mathrm{bw}$ & 35.02 & 42.79 \\
ACLE $100 \mathrm{mg} / \mathrm{kg}$ bw & 52.50 & 47.97 \\
SALE $50 \mathrm{mg} / \mathrm{kg}$ bw & -12.97 & -14.84 \\
SALE $100 \mathrm{mg} / \mathrm{kg}$ bw & 48.21 & 60.69 \\
ACLE-SALE combination $(25-25 \mathrm{mg} / \mathrm{kg} \mathrm{bw})$ & 54.77 & 67.60 \\
ACLE-SALE combination $(50-50 \mathrm{mg} / \mathrm{kg} \mathrm{bw})$ & 25.46 & 34.62 \\
\hline
\end{tabular}

Percent inhibition of blood pressure elevation was compared with the blood pressure elevation of positive control group as shown in table 2. Combination of ACLE-SALE (25-25 mg/ $\mathrm{kg} \mathrm{bw})$ showed the best effect with inhibition on SBP and DBP as much as $54.77 \%$ and $67.60 \%$ respectively. From table 2 , it can also be seen that the effect of ACLE and SALE combination was synergistic based on the blood pressure from ACLESALE $25-25 \mathrm{mg} / \mathrm{kg}$ bw group that had higher inhibition than ACLE and SALE administered individually with $50 \mathrm{mg} / \mathrm{kg}$ bw dose. In addition, the effect seen from administration of ACLE-SALE 25-25 mg/ $\mathrm{kg}$ bw was comparable to the effect of SALE $100 \mathrm{mg} / \mathrm{kg}$ bw.

\section{CONCLUSION}

Significant decrease in blood pressure after induction was seen in ACLE $50 \mathrm{mg} / \mathrm{kg}$ bw and ACLE-SALE $(25-25 \mathrm{mg} / \mathrm{kg} \mathrm{bw})$ groups. This signify that those extracts have potential antagonist effect against angiotensin II on AT1 receptor. Furthermore, SALE of $25 \mathrm{mg} / \mathrm{kg}$ bw in combination with ACLE managed to lower the dose of ACLE as antihypertension by half the single dose tested with comparable result. In addition, the 25$25 \mathrm{mg} / \mathrm{kg}$ bw extract combination also showed comparable blood pressure to SALE $100 \mathrm{mg} / \mathrm{kg}$ bw administration while SALE $50 \mathrm{mg} / \mathrm{kg}$ bw did not showed antihypertensive effect. The highest percent inhibition of blood pressure elevation was seen in ACLE-SALE $(25-25 \mathrm{mg} / \mathrm{kg}$ bw) group. Hence, combination of ACLE-SALE $(25-25 \mathrm{mg} / \mathrm{kg} \mathrm{bw})$ was the most effective experimental treatment in this study in lowering the effect of angiotensin II.

\section{MATERIALS AND METHODS}

\subsection{Chemicals}

Human Angiotensin II (Santacruz sc363643), sodium chloride 0,9\%, binahong leaves, tempuyung leaves, Valsartan (Diovan $\left.{ }^{\circledR}\right)$, ethanol, distilled water, Na-CMC, chloroform, toluene, ammonia, Dragendorff's reagent (bismuth subnitrate in acetic acid and sodium nitrate), Mayer's reagent (mercury (II) chloride and potassium iodide in water), Stiasny's reagent (concentrated hydrochloric acid and formaldehyde), Lieberman-Burchard reagent (concentrated sulfuric acid and acetic anhydride), potassium hydroxide, magnesium, concentrated hydrochloric acid, amyl alcohol, iron (III) chloride, gelatin, sodium acetate, sodium hydroxide, and ether. 


\subsection{Apparatuses}

Reflux apparatus, rotary evaporator, and CODA® tail-cuff blood pressure system plethysmograph.

\subsection{Animals}

Male Wistar rats were obtained from animal laboratory school of pharmacy, Bandung Institute of Technology (ITB). A total of 27 rats were between 4 to 5 months of age with body weight between 250-350 g. Rats were housed according to their experimental group with 12-hour of light/dark cycle. Experimental procedures performed had been approved by the Animal Research Ethics Committee of ITB.

\subsection{Plant materials}

Anredera cordifolia (Ten.) v. Steenis and Sonchus arvensis L. from here onward will be referred to as AC and SA respectively. AC and SA leaves were obtained from Manoko Herbal Medicine Plantation which is located in Lembang, a subdistrict located West Bandung District in West Java, Indonesia. Both plants materials were identified in the Herbarium 'Herbarium Bandungense' owned and operated by the School of Life Science and Technology, Bandung Institute of Technology. The identification document number from the Herbarium were 3038/11.CO2.2/PL/2017 and 3823/11.CO2.2/PL/2010 for AC and SA respectively. For the preparation, both plants' leaves were thoroughly washed, sorted, and chopped into smaller parts, then dried using oven at $50-60^{\circ} \mathrm{C}$ over a few days. The dried leaves were then grounded into powder prior to extraction.

\subsection{Extraction}

The powdered AC and SA leaves were individually extracted with $96 \%$ ethanol using the reflux apparatus over 2 hours at $60^{\circ} \mathrm{C}$. Extracts were filtered, and filtrates were obtained while the residues were reextracted twice following the same method. All filtrates for each plant were combined and its solvent was evaporated using rotary evaporator to obtain concentrated AC and SA leaves extracts.

\subsection{Preparation of test substances}

AC leaves extract, SA leaves extract and comparator were each suspended in $0.5 \%$ Na-CMC previously dissolved in distilled water and prepared accordingly based on the dose of administration. Each extract was prepared in $1 \%$ and $2 \%$ concentration while valsartan was prepared in $0.1 \%$ concentration. Human Angiotensin II (Santacruz sc363643) was prepared by making $0.004 \%$ of angiotensin II dissolved in $0.9 \% \mathrm{NaCl}$ to induce hypertension.

\subsection{Antihypertensive activity assay}

Prior to the experiment, all rats were habituated to the CODA® tail-cuff blood pressure system plethysmograph. A total of 27 rats were divided randomly into 9 groups which are negative control, positive control, comparator group treated with valsartan, test groups treated with AC leaves extract (ACLE) dose 100 $\mathrm{mg} / \mathrm{kg} \mathrm{bw}$, ACLE dose $50 \mathrm{mg} / \mathrm{kg}$ bw, SA leaves extract (SALE) dose $100 \mathrm{mg} / \mathrm{kg}$ bw, SALE dose $50 \mathrm{mg} / \mathrm{kg}$ $\mathrm{bw}$, and combination of ACLE and SALE with 50-50 and $25-25 \mathrm{mg} / \mathrm{kg}$ bw respectively. Negative control group is the group that was not angiotensin induced and therefore displayed no hypertension. The negative control group also was untreated with extract or comparator drug. While the positive control group is the group that was angiotensin induced, hence displaying hypertension, and was untreated and only received oral administration of $0.5 \%$ CMC-Na. At the start of the experiment, all rats were measured for their systolic and diastolic blood pressure using CODA ${ }^{\circledR}$ tail-cuff blood pressure system as $\mathrm{T} 0$. Then, all treatments were administered orally according to the experimental groups. An hour after treatments administration, $100 \mu \mathrm{g} / \mathrm{kg}$ bw of angiotensin II was injected intraperitonially. Then, after three minutes, the systolic and diastolic blood pressure were measured as T1 [20]. Throughout the experiment, it was especially important to keep the environment calm and least stressful for the rats to ensure unbiased blood pressure measurement.

\subsection{Statistical analysis}

Statistical analysis was done to compare systolic and diastolic blood pressure from test groups against positive control group using one-way ANOVA with LSD post-hoc test. The results were considered to be statistically significant when $\mathrm{p}<0.05$.

\section{Appendix A. Supplementary Material}

Supplementary material related to this article can be accessed at http://doi.org/10.35333/jrp.2019.73. 
Acknowledgements: We would like to thank Bandung Institute of Technology for providing the funding for this research. We also thank the School of Pharmacy, Bandung Institute of Technology for the support and permission to use the laboratory of pharmacology facilities to conduct the research.

Author contributions: Concept - E.Y.S., A.N.G, A.U.A; Design - E.Y.S., A.N.G, A.U.A; Supervision - E.Y.S., A.N.G; Resources - E.Y.S., A.N.G, A.U.A ; Materials - E.Y.S., A.N.G, A.U.A.; Data Collection and/or Processing - A.U.A, A.A.C.; Analysis and/or Interpretation - E.Y.S., A.N.G, A.U.A., A.A.C.; Literature Search - A.U.A., A.A.C.; Writing A.U.A., A.A.C.; Critical Reviews - E.Y.S., A.N.G, A.U.A., A.A.C.

Conflict of interest statement: The authors declared no conflict of interest.

\section{REFERENCES}

[1] WHO Noncommunicable Diseases (NCD) Country Profiles: Indonesia. http://www.who.int/nmh/countries/idn_en.pdf (accessed July 20, 2018).

[2] World Health Organization. The top 10 causes of death. http://www.who.int/news-room/fact-sheets/detail/thetop-10-causes-of-death (accessed July 20, 2018).

[3] Badan Penelitian dan Pengembangan Kesehatan Kementerian Kesehatan RI: Riset Kesehatan Dasar (RISKESDAS) 2013. http://www.depkes.go.id/resources/download/general/Hasil\%20Riskesdas\%202013.pdf (accessed July 20, 2018).

[4] Nafrialdi, Gunawan SG, Farmakologi dan Terapi, 5th ed., Balai Penerbit FKUI, Jakarta, Indonesia, 2013.

[5] Miladiah I, Prabowo BR. Ethanolic extract of Anredera corfifolia (Ten.) Steenis leaves Improved wound healing in guinea pigs. Univ Med. 2012; 31: 4-11.

[6] Astuti SM, AM Sakinah M, BM Retno A, Risch A. Determination of Saponin Compound from Anredera cordifolia (Ten.) Steenis Plant (Binahong) to Potential Treatment for Several disease. J Agric Sci. 2011; 3(4): 224-232. [CrossRef]

[7] Sukandar EY, Ridwan A, Sukmawan YP. Vasodilation Effect of Oleanolic Acid and Apigenin As a Metabolite Compound of Anredera Cordifolia (Ten) V. Steenis on Isolated Rabbit Aortic and Frog Heart. Int J Res Ayurveda Pharm. 2016; 7(5): 82-84. [CrossRef]

[8] Wahjuni S. Anti-hipercholesterolemia of Anredera Cordifolia in Hypercholesterolemia Rat Wistar Through Decrease of Malondialdehyde and 8-Hydroxy-Diguanosine. Indonesia Jounal of Biomedical Science. 2014; 8(1): 4-7. [CrossRef]

[9] Garmana AN, Sukandar EY, Fidrianny I. Preliminary study of blood pressure lowering effect of Anredera cordifolia (Ten.) steenis) on Wistar rats. Int J Pharmacogn Phytochem Res. 2016; 8(2): 300-304.

[10] Rohaeti E, Heryanto R, Rafi M, Wahyuningrum A, Darusman LK. Prediksi Kadar Flavonoid Total Tempuyung (Sonchus arvensis L.) Menggunakan Kombinasi Spektroskopi IR dengan Regresi Kuadrat Terkecil Parsial. Jurnal Kimia (Journal of Chemistry). 2011; 5(2): 101-108.

[11] Yuliarti W, Kusrini D, Fachriyah E. Isolasi, Identifikasi dan Ui Antioksidan Asam Fenolat dalam Daun Tempuyung (Sonchus arvensis L.) dengan Metode 1,1-difenil-2-pikrilhidrasil (DPPH). Chem Info. 2013; 1(1): $294-304$.

[12] SulaksanaJ, Santoso B, Jayusman DI, Tempuyung: Budi Daya dan Pemanfaatan untuk Obat, 1 $1^{\text {st }}$ Ed., Penebar Swadaya, Jakarta, 2004.

[13] Khan RA. Evaluation of flavonoids and diverse antioxidant activities of Sonchus arvensis. Chem Cent J. 2012; 6(126): 1-7. [CrossRef]

[14] Suryani, Sukandar EY, Sutjiatmo AB, Vikasari SN. Angiotensin Converting Enzyme Inhibitor Activity of Ethanol Extract of Sonchus Arvensis (Linn.) Leaves. In: The 6th International Conference. 2017. p. 124-128.

[15] Muhtadi, Wahyuningtyas N, Sutrisna EM, Suhendi A, Anggoro BKS. Efek Diuresis Dari Kombinasi Ekstrak Salam (Syzygium polyanthum Wight.) dan Tempuyung (Sonchus arvensis L.) pada Mencit Hiperurisemia. 4th Univ Res Coloquium 2016. 2016; 22-27.

[16] James PA, Oparil S, Carter BL, Cushman WC, Dennison-Himmelfarb C, Handler J, Lackland DT, LeFevre ML, MacKenzie TD, Ogedegbe O, Smith SC, Svetkey LP, Taler SJ, Townsend RR, Wright JT, Narva AS, Ortiz E. 2014 Evidence-Based Guideline for the Management of High Blood Pressure in Adults: Report From the Panel Members Appointed to the Eighth Joint National Committee (JNC 8). JAMA. 2014; 311(5): 507. [CrossRef]

[17] National Center for Biotechnology Information. PubChem Compound Database; CID=172198. https://pubchem.ncbi.nlm.nih.gov/compound/172198 (accessed 15 May 2018). 
[18] Berridge MJ, Irvine RF. Inositol triphosphate, a novel second messenger in cellular signal transduction. Nature. 1984; 312: 315-21. [CrossRef]

[19] Kawai T, Forrester SJ, O’Brien S, Baggett A, Rizzo V, Eguchi S. AT1 receptor signaling pathways in the cardiovascular system. Pharmacol Res. 2017; 125: 4-13. [CrossRef]

[20] Ohno O, Ye M, Koyama T, Yazawa K, Mura E, Matsumoto H, Ichino T, Yamada K, Nakamura K, Ohno T, Yamaguchi K, Ishida J, Fukamizu A, Uemura D. Inhibitory effects of benzyl benzoate and its derivatives on angiotensin IIinduced hypertension. Bioorganic Med Chem. 2008; 16: 7843-52. [CrossRef]

This is an open access article which is publicly available on our journal's website under Institutional Repository at http://dspace.marmara.edu.tr. 